\title{
Performance of broilers fed water-soluble blood meal during growing and finishing period
}

\author{
M. A. Habib ${ }^{*}$ M. Shahidullah ${ }^{1}$ and M. A. Ali ${ }^{2}$ \\ Department of Animal Breeding and Genetics, Faculty of Animal Husbandry, Bangladesh \\ Agricultural University, Mymensingh-2202, Bangladesh
}

\begin{abstract}
The effect of water-soluble blood meal was tested on the performance of broilers. Forty broiler chickens aged 21 days were reared on slatted floor and the dietary treatments were $T_{0}, T_{1}, T_{2}$ and $T_{3}$ where $0,0.25,0.50$ and $0.75 \mathrm{~g}$ blood meal was given/L drinking water, respectively. The blood meal significantly enhanced the growth and feed conversion efficiency. The weight gain and net profit was significantly $(p<0.001)$ higher in chickens with $0.25 \mathrm{~g} / \mathrm{L}$ blood meal in water. It is suggested that blood meal at $0.25 \mathrm{~g} / \mathrm{L}$ may be used in drinking water during growing and finishing period of broilers for better performance. (Bangl. vet. 2009. Vol. 26, No. 1, 8-12)
\end{abstract}

\section{Introduction}

Commercial poultry production started from 1980 in Bangladesh and now the industry involves US \$ 1-5 billion investment and employs 3-5 million people. There are 3 million broiler parent stock producing 260 million day-old broiler chicks every year (Kabir, 2005).

Many private breeder and commercial poultry farms have been established, but in recent years many of them have stopped growing due to high price of feed and chicks. Generally, feed cost accounts for $60-70 \%$ of the total running costs of a poultry farm. Many unconventional feed ingredients are available in Bangladesh. Blood meal is one. It contains more than $80 \%$ crude protein (Sanger, 1981). It is one of the richest sources of lysine, a rich source of arginine, methionine, cystine, and leucine, but is very poor in isoleucine and contains less glycine than fish meal or bone meal (NRC, 1994). Compared with vegetable protein in poultry diet it is quite high in biological value. Generally vegetable protein is deficient in lysine and methionine (McDonald et al., 1992). Blood meal contains certain minerals particularly iron and copper. Blood meal can be incorporated at $1-4 \%$ in the poultry diet for better growth (Petkov et al., 1980; Nuarautelli et al., 1987; Ikram et al., 1989). Slinger et al. (1955) stated that a combination of blood meal and keratin meal did not promote better growth than blood meal alone. Batterham et al. (1986) stated that the addition of lysine in the diet containing blood meal promoted growth. Dafwang et al. (1986) stated that the

\footnotetext{
1 Department of Physiology, Faculty of Veterinary Science, Bangladesh Agricultural University, Mymensingh, Bangladesh

2 Department of Poultry Science, Faculty of Animal Husbandry, Bangladesh Agricultural University, Mymensingh, Bangladesh

*Correspondence: E-mail:- ahsan.rony@yahoo.com
} 
inclusion of both fish meal and blood meal tended to improve performance. The absence of these ingredients increased cannibalism and mortality. But in contrast Toor and Fahimullah (1972); Hassan et al. (1974); Onwudike (1981) obtained good growth of chickens with higher level of blood meal. Water-soluble blood meal is now available, but no comprehensive report is available about the effect of water-soluble blood meal on broiler performance. This study was undertaken to investigate the effect of different levels of blood meal on the performance of broilers.

\section{Materials and Methods}

The experiment was conducted at a private farm, Agricultural research and development farm (ARDF), Sutiakhali, Mymensingh. The experimental house was cleaned, washed with tap water and disinfected with gluteraldehyde+cocobenzyl dimethyl ammonium chloride (Omnicide ${ }^{\circledR}$, Vetcare, India) solution. The house was left empty for two weeks before placing the experimental birds. A total of 500 one-dayold "Hubbard classic" chicks were purchased from the Pacific Hatchery, Valuka, Mymensingh. The birds were brooded with electric brooder for three weeks. Light was given for 23 hours/day to acclimatise to the environment. The birds were reared on slatted floor. In order to prevent stress and bacterial infection Dextrose monohydrate100\% (Glucose ${ }^{\circledR}$, Glaxosmithkline, Chittagong, Bangladesh) administered @ 50g/litre of water for few hours before supplying feed and Oxytetracycline (Renamycin ${ }^{\circledR}$, Renata Animal Health, New DOHS, Mohakhali, Dhaka, Bangladesh) @ 0.25 g/litre of water was given in first three days and again at 20-22 days of age. Water-soluble multivitamins (Megavit ${ }^{\circledR}$ WS, Novartis Animal Health, Bangladesh Ltd, Dhaka, Bangladesh) @ $0.2 \mathrm{~g} /$ litre of water were given for three consecutive days in every weeks. The birds were vaccinated with Baby Chick Ranikhet Disease Vaccine (BCRDV ${ }^{\circledR}$, Livestock Research Institute, Mohakhali, Dhaka, Bangladesh) against Newcastle disease (ND) @ one eye drop per bird at four days of age and a booster dose was given at 14 days of age and Infectious Bursal Disease (IBD) vaccine (Gumboro BAU 404 ${ }^{\circledR}$, Livestock Research Institute, Mohakhali, Dhaka, Bangladesh) @ one eye drop was given per bird at seven days of age and a booster at 18 days of age.

The feeds manufactured by Nourish Poultry Feeds Ltd. Dhaka, Bangladesh were provided ad libitum throughout the experiment. The broiler starter diet in the form of crumble was supplied from 1 to 28 days of age and finisher diet in the form of pelleted from 29 to 35 days of age. Fresh drinking water was available all the time. At 21 days of age, 40 male birds of uniform size were selected and wing-banded for the experiment. The birds were distributed to four dietary groups: $T_{0}, T_{1}, T_{2}$ and $T_{3}$ having ten birds in each group. The birds were reared on slatted floor with an area of $3.0 \times 2.5$ feet in each group. Processed water-soluble blood meal was collected from the local market and mixed into the drinking water. $\mathrm{T}_{0}$ was control where no blood meal was provided; $T_{1}, T_{2}$ and $T_{3}$ were supplied blood meal at $0.25,0.50$ and $0.75 \mathrm{~g} /$ litre of water from 22 to 35 days of age. 
The body weight was recorded at 21 and 35 days of age. Group feed intake was recorded weekly. The feed efficiency was calculated. No mortality was observed during experimental period. The cost-benefit was calculated by deducting the cost of chick, feed, vaccine, medicine and others from the gross income.

The parameters were analyzed by Completely Randomized Design (CRD). Significant differences were identified by least significance difference (LSD) using SPSS-11.50 programme.

\section{Results and Discussion}

Growth of broilers was significantly $(\mathrm{p}<0.001)$ improved by the addition of blood meal (Table 1). The weight gain (22-35 days) of broilers was significantly higher in $\mathrm{T}_{1}$ than $\mathrm{T}_{0}$ and $\mathrm{T}_{3}$ (Table 1). The result is consistent with Petkov et al. (1980), Nuarautelli et al. (1987), Ikram et al. (1989) and Khawaja et al (2007) who reported that blood meal can be effectively used at up to $3 \%$ of the diet of broilers for optimum growth. However, weight gain can be reduced with higher levels of blood meal and this might be due to low levels of the sulphur-containing amino acids and isoleucine (Onwudike, 1981). Hassan et al. (1974) used $6 \%$ blood meal with $15 \%$ meat meal in broiler diet without adverse effect on growth rate, because meat meal is a good source of B vitamins, with other unidentified beneficial factors. Rahman (1995) studied the growth performance of broilers with different levels of blood meal in the diet and found significant $(\mathrm{p}<0.05)$ differences in growth at 35 days of age. He suggested that

$2 \%$ blood meal may be included in the broiler diet for optimum performance. Squibb and Braham (1955) stated that blood meal was most effective when fed at 2 to $4 \%$ of the diet. Slinger et al. (1955) reported that 3\% blood meal with crystalline lysine produced better growth in poultry. $\mathrm{T}_{1}$ group showed better feed conversion efficiency than other groups (Table 1). The feed conversion efficiency with $2.5 \%$ blood meal was best. This might be due to the fact that blood meal is rich in lysine, arginine, methionine, cystine, and leucine. The result is consistent with Friedhelm et al. (2002), Subhadra et al. (2006) and Khawaja et al. (2007), but differs from the observation of Rahman (1995) who found insignificant $(p>0.05)$ difference of FCR with different levels of blood meal.

The highest net profit was obtained in $\mathrm{T}_{1}$ with $2.5 \%$ blood meal (Table 2). The total return from sale of birds ranged from Taka 112.0-129.5 as against the total expenditure of Taka 102.1 - 114.7. The net return per bird ranged from Taka 7.8 - 22.9. The cost-benefit analysis indicated that $2.5 \%$ blood meal gave maximum profit. Petkov et al. (1980) reported that chicks fed diet containing 3\% blood meal showed most economic benefit. The result is similar to the observation of Khawaja et al. (2007). Low prices of blood meal, better feed efficiency and weight gain with $2.5 \%$ blood meal $\left(T_{1}\right)$ were responsible for better net profit. 
Table 1. Performance (Mean \pm SE) of broilers fed different levels of blood meal in drinking water

\begin{tabular}{|c|c|c|c|c|c|c|c|c|}
\hline \multirow{3}{*}{$\begin{array}{l}\text { Treatment } \\
\text { group }\end{array}$} & \multirow{3}{*}{$\begin{array}{c}\text { Day-old } \\
\text { weight } \\
(\mathrm{g})\end{array}$} & \multicolumn{7}{|c|}{ Performance parameter (mean \pm SE) } \\
\hline & & \multirow{2}{*}{$\begin{array}{c}21 \text { day } \\
\text { weight }(g)\end{array}$} & \multirow{2}{*}{$\begin{array}{c}35 \text { day } \\
\text { weight (g) }\end{array}$} & \multirow{2}{*}{$\begin{array}{c}\text { Weight gain } \\
\text { (4-5 weeks) } \\
\text { (g) }\end{array}$} & \multicolumn{3}{|c|}{ Feed intake $(\mathrm{g})$} & \multirow{2}{*}{$\begin{array}{c}\text { FCE } \\
\text { (4-5 weeks) }\end{array}$} \\
\hline & & & & & $\begin{array}{c}0-3 \\
\text { weeks }\end{array}$ & $\begin{array}{c}4-5 \\
\text { weeks }\end{array}$ & Total & \\
\hline $\mathrm{T}_{0}(0 \%)$ & 43 & $1020 \pm 8.2$ & $1600^{\mathrm{a}} \pm 25.8$ & $580^{\mathrm{a}} \pm 27.1$ & 2010 & 1110 & 3120 & 1.9 \\
\hline $\mathrm{T}_{1}(2.5 \%)$ & 42 & $1025 \pm 13.4$ & $1850^{\mathrm{b}} \pm 34.2$ & $825^{b} \pm 37.5$ & 1850 & 1390 & 3240 & 1.7 \\
\hline $\mathrm{T}_{2}(5.0 \%)$ & 43 & $1020 \pm 8.2$ & $1800^{b c} \pm 25.8$ & $780^{\mathrm{bc}} \pm 27.1$ & 1880 & 1360 & 3240 & 1.7 \\
\hline $\mathrm{T}_{3}(7.5 \%)$ & 43 & $1015 \pm 10.7$ & $1750^{\mathrm{cd}} \pm 26.9$ & $725^{\mathrm{cd}} \pm 25.0$ & 1925 & 1315 & 3240 & 1.8 \\
\hline
\end{tabular}

Table 2. Economic analysis of broilers fed different level of blood meal (0-35days)

\begin{tabular}{l|c|c|c|c}
\hline \multirow{2}{*}{ Parameters } & \multicolumn{4}{c}{ Treatment group } \\
\cline { 2 - 5 } & $\mathrm{T}_{0}$ & $\mathrm{~T}_{1}$ & $\mathrm{~T}_{2}$ & $\mathrm{~T}_{3}$ \\
\hline Feed consumed from 0-3 weeks (kg/bird) & 2.0 & 1.9 & 1.9 & 1.9 \\
Feed consumed from 4-5 weeks (kg/bird) & 1.1 & 1.4 & 1.4 & 1.3 \\
Total feed consumed (kg/bird) & 3.1 & 3.2 & 3.2 & 3.2 \\
Cost of feed @ 23.8 *Taka/kg ("Taka/bird) & 73.0 & 74.3 & 74.4 & 75.6 \\
Chick cost ("Taka/chick) & 24.0 & 24.0 & 24.0 & 24.0 \\
Cost of blood meal ("Taka/bird) & 00.0 & 3.3 & 6.8 & 10.0 \\
Vaccine, medicine, electricity ("Taka/bird) & 5.1 & 5.1 & 5.1 & 5.1 \\
Total cost ("Taka/bird) & 102.1 & 106.6 & 110.2 & 114.7 \\
Average live weight at 35 days (kg/bird) & 1.6 & 1.9 & 1.8 & 1.8 \\
Return on sale of live broiler @ *Taka 70 & 112.0 & 129.5 & 126.0 & 122.5 \\
per kg & & & & \\
Net profit per bird ("Taka) & 9.9 & 22.9 & 15.8 & 7.8 \\
\hline
\end{tabular}

* 1 Taka $=0.01435$ US $\$$ (or 1 US $\$=69.66$ Taka) as on $10^{\text {th }}$ November, 2007

It may be concluded that blood meal at a level of $2.5 \%$ may be incorporated in drinking water of broilers for optimum performance with greatest economic benefit.

\section{Acknowledgements}

The authors are highly grateful to Agricultural Research and Development Farm (ARDF), Sutiakhali, Mymensingh for their cordial co-operation and support.

\section{References}

Batterham ES, Lowe RF, Darnell RE, Major EJ 1986: Available of lysine in meat meal, meat and bone meal and blood meal as determined by the slope-ratio assay with growing pigs, rats and chicks and by chemical techniques. British Journal of Nutrition 55 427-440. 
Dafwang II, Olumu JM, Offiong SA, Bello S 1986: The effects of replacing fish meal with blood meal in the diets of laying chickens. Journal of Animal Production Research 6 81-92.

FAO (Food and Agriculture Organization) 1999: Production Year Book. Rome, Italy.

Friedhelm KP, Wijtten PJA, Lemme A, Langhout DJ 2002: Impact of a balanced amino acid profile on broiler performance. Veterinaria in Zootechnika T 19 70-75.

Hassan OEM, Mukhtar AMS, Nasir MEA 1974: The use of blood meal in tropical broiler diets. Tropical Animal Health and Production 6 179-182.

Ikram H, Ahmed MN, Ehtisham MM 1989: Effect of different levels of blood meal on broiler performance. Pakistan Journal of Veterinary Research 2 51-54.

Kabir SSK 2005: Poultry in Bangladesh: Awaiting the awakening. Proceedings of the $4^{\text {th }}$ International Poultry Show and Seminar. World's Poultry Science Association (BB), Dhaka, Bangladesh. pp. 8-15.

Khawaja T, Khan SH, Ansari NN 2007: Effect of Different Levels of Blood Meal on Broiler Performance during Two Phases of Growth. International Journal of Poultry Science 6 860-865.

McDonald, Edwards P, Greenhalgh JFD 1992: Animal Nutrition. $4^{\text {th }}$ ed. Published in the United States with John Wiley and Sons. Inc. New York pp. 455-483.

NRC 1994: Nutrient requirement for Poultry. $9^{\text {th }}$ Ed. National Academy Press. Washington DC, USA.

Nuarautelli A, Anghinelli A, Blanco A 1987: Use of spray dried blood meal in broiler diet. Medicinia Veterinaria, Universita di Parma, Italy pp. 333-353.

Onwudike O C 1981: Effect of various protein sources on egg production in a tropical environment. Tropical Animal Production 6 249-256.

Petkov S, Kacervsky O, Sova Z, Kalous I, Slauk L, Bouska F, Jedlicka Z, Stradel M, Parizokova L 1980: Possible part or complete replacement of animal meals by spray dried blood from preserved or non preserved blood in feeds for broilers, Nutrition Abstract Review 51135.

Rahman M 1995: Effects of blood meal in broiler ration. MSc Thesis. Department of Poultry Science, Faculty of Animal Husbandry, Bangladesh Agricultural University, Mymensingh.

Sanger SS 1981: Low cost ration formulation in Poultry, Poultry Adviser 15 25-29.

Slinger SJ, Pepper WF, Hill DC 1955: The use of keratin products in poultry ration. Poultry Science 34919 - 922.

Squibb RL, Braham JE 1955: Blood meal as a lysine supplement to all vegetable protein rations for chicks, Poultry Science 341050 - 1053.

Subhadra B, Rebecca L, Steven R, Ruguang C 2006: Improving the production efficiency and sustainability of Morone species culture. Aquaculture 260 221-231.

Toor AA, Fahimullah 1972: Effects of different levels of blood meal on the performance of broiler chick. MSc Thesis. Department of Poultry Husbandry, University of Agriculture, Faisalabad, Pakistan. 